\title{
Big Banks in Small Places: Are Community Banks Being Driven Out of Rural Markets?
}

\author{
$\underline{\text { R. Alton Gilbert and David C. Wheelock }}$
}

\begin{abstract}
The shares of total U.S. banking assets and deposits held by the very largest banking organizations have increased markedly over the past 25 years, while the shares held by small "community" banks have declined. Advances in information technology may have reduced the advantages of small scale, close proximity, and local ties that traditionally have given small, community-focused banks a competitive advantage in lending to small businesses and other "informationally opaque" borrowers. This article examines trends in deposit shares of banks of different sizes in rural U.S. counties. If the community banking model is to remain viable, it is likely to be in rural markets with (i) a relatively high percentage of informationally opaque borrowers and (ii) relatively low costs of acquiring qualitative information about potential borrowers. The authors find that rural deposit shares of both the smallest and very largest banking organizations changed little between 2001 and 2012, despite the upheavals of the financial crisis and recession, and in contrast to the 1980s and 1990s, when the shares held by the smallest banks declined markedly. The evidence suggests that well-managed community banks remain competitive, at least in rural markets, where their niche is most likely stronger than in urban markets. (JEL G21, G28, L1)
\end{abstract}

Federal Reserve Bank of St. Louis Review, May/June 2013, 95(3), pp. 199-218.

\footnotetext{
R. Alton Gilbert is an economist emeritus and David C. Wheelock is a vice president and deputy director of research at the Federal Reserve Bank of St. Louis. The authors thank Dean Amel, Fernando Martin, Andrew Meyer, and Kenneth Spong for comments on a previous version of this article. David L. Lopez provided research assistance.

○ 2013, The Federal Reserve Bank of St. Louis. The views expressed in this article are those of the author(s) and do not necessarily reflect the views of the Federal Reserve System, the Board of Governors, or the regional Federal Reserve Banks. Articles may be reprinted, reproduced, published, distributed, displayed, and transmitted in their entirety if copyright notice, author name(s), and full citation are included. Abstracts, synopses, and other derivative works may be made only with prior written permission of the Federal Reserve Bank of St. Louis.
} 


\section{Gilbert and Wheelock}

The relaxation of state and federal government restrictions on branching removed an important impediment to consolidation of the banking industry. In 1984, more than half of all U.S. banks were "unit banks" - that is, they had only one office; in 2011, only one-tenth of all banks were unit banks. 1 The Riegle-Neal Interstate Banking and Branching Efficiency Act of 1994 allowed banks to branch across state lines, and several banks now operate branches in multiple states, including JPMorgan Chase with 5,488 domestic branches and Bank of America with 5,755 domestic branches as of December 31, 2011.

As very large banks have seen their shares of total U.S. banking assets and deposits rise, small banks have seen their shares dwindle. Between 2001 and 2012, for example, the shares of total U.S. commercial bank assets and deposits held by banks with less than $\$ 1$ billion in assets declined from 16 percent and 20 percent, respectively, to 9 percent and 10 percent. $\frac{2}{2}$ The continuing decline in shares held nationally by small banks has raised the question whether small, community-focused banks can remain economically viable. Analysts point to both public policies and technological changes as favoring larger banks over their smaller competitors. For example, the treatment of very large banks as too big to fail could allow large banks to attract depositors and issue other forms of debt less expensively than smaller banks. The Dodd-Frank Wall Street Reform and Consumer Protection Act of 2010 is intended to eliminate such too-big-to-fail protections, but some analysts are skeptical. If the public perceives that the government will protect depositors and other creditors of very large banks from loss, but not afford similar protection to creditors of smaller institutions, then smaller banks will be competitively disadvantaged. $\underline{3}$

Technological changes, particularly advances in information-processing technology, may also favor larger banks. Such advances have lowered the costs of obtaining "hard" information about potential borrowers, such as audited financial statements and standardized credit reports. At the same time, these changes have also lowered the cost to banks of monitoring deposit and loan accounts and managing large branch networks. Thus, technological changes may have reduced the advantages of small scale, close proximity, and local ties that traditionally have given small, community-focused banks a competitive advantage in lending to small businesses and other borrowers for which hard data do not exist or are limited (Petersen and Rajan, 2002; Berger, 2003; Bernanke, 2006).

Despite public policies and technological advances that appear to favor large banks with far-flung operations, many community banks continue to thrive, even in challenging times such as the recent financial crisis and recession (Gilbert, Meyer, and Fuchs, 2013). Further, some studies conclude that the community bank business model, with its focus on lending to small businesses and consumers on the basis of "soft" information derived from customer relationships, community ties, and so forth, remains viable for well-managed banks (see, e.g., DeYoung, Hunter, and Udell, 2004). The jury is still out, however, about whether the evolving structure of the U.S. banking system will retain a place for community banks over the long run.

The Federal Deposit Insurance Corporation (FDIC, 2012) recently released a comprehensive study of community banks. The study compares the performance of community and noncommunity banks, community bank lending patterns, capital strategies, locations, and trends in market share in different-sized banking markets. The study reports several important findings. For example, it shows that the share of U.S. banking assets held by community banks declined 
by more than 50 percent between 1984 and 2011. The study also finds that, in general, community banks have been less profitable than other banks. However, community banks remain the only banking presence in more than 600 counties (nearly 20 percent of all U.S. counties) and they continue to hold the majority of banking deposits in rural counties and small cities. The study finds that community bank market shares declined between 1984 and the early 1990s in both rural counties and small cities, as well as in urban markets, but their share of rural county markets changed little between 2000 and 2011. The FDIC study does not draw strong conclusions about the long-term viability of the community bank business model. However, the study notes that economic and population growth were slower during the past decade in rural counties and small cities than in urban markets; and, if those trends continue, the growth opportunities for community banks may be limited.

This article examines trends in the deposit market shares of small, mid-sized, and very large banking organizations in rural U.S. banking markets between 2001 and 2012. Although community banks operate in both rural and urban markets, we focus on rural markets because the performance of community banks in rural markets is likely to be more informative about the viability of the community bank business model, with its focus on relationship lending and reliance on core deposits. The financial reports that banks file with regulators provide little information about bank customers. Data on small-denomination loans to businesses and farmers are available, but the borrowers of these small-denomination loans are not necessarily smallbusiness enterprises. Similarly, banks report information on deposits in accounts below the federal deposit insurance limit, but these data do not reveal the income or wealth of the depositors. We assume that bank offices in rural areas are more likely to conduct banking business with households and small businesses than banks in urban areas and therefore are more likely to engage in traditional banking activities, such as making loans on the basis of customer relationships and other soft information in which community banks are thought to specialize. ${ }^{4}$ Thus, if we were to find evidence that very large banks with far-flung operations are beginning to dominate rural markets, it would suggest that the community bank model may not be viable. That conclusion, in turn, would have implications for small businesses and other customers that traditionally have relied on community banks, as well as for the banks themselves.

\section{LITERATURE REVIEW}

\section{Possible Advantages of Community Banks Lending to Small Businesses}

Many studies have addressed questions about the viability of the community bank business model. Some researchers argue that community banks have a comparative advantage in lending to "informationally opaque" borrowers, such as entrepreneurs, small businesses, and other borrowers for which audited accounting information, credit reports, and other hard information are limited.

One reason community banks may have an advantage in lending to informationally opaque borrowers is that managers of community banks typically have more control over the allocation of their banks' resources than do branch managers of large banks with far-flung operations. 


\section{Gilbert and Wheelock}

Stein (2002) argues that this control gives managers of community banks more incentive to develop relationships with potential customers and to take other steps to acquire qualitative information about borrowers, which may lead to more-informed credit decisions about infor-

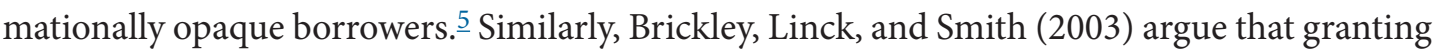
significant decisionmaking authority to local bank managers facilitates lending on the basis of qualitative information. However, to control agency problems, managers with a high degree of authority must have an ownership stake or be closely monitored by local stockholders, which generally is not possible in large banks with widely dispersed offices. Hence, Brickley, Linck, and Smith (2003) argue that small, locally owned banks are likely to dominate in small urban and rural markets where small businesses and other informationally opaque borrowers are the predominant loan customers.

Empirical evidence has tended to support economic theory in finding that community banks lend disproportionately to small businesses and other informationally opaque borrowers. By contrast, large banks lend mainly to larger firms with good accounting information and households on the basis of credit ratings and other reliable quantitative information (Berger et al., 2005). Further, research finds that community banks (i) rely more heavily on developing customer relationships and investing in other forms of qualitative information and (ii) account for larger shares of banking business in smaller urban and rural markets than in large urban markets. Cole, Goldberg, and White (2004), for example, examine lending to small businesses, as reported in a 1993 Federal Reserve survey. The authors find that large banks are more likely to rely primarily on standard accounting records and other quantitative information in making credit decisions, whereas small banks use a more discretionary approach based heavily on preexisting customer relationships. Using the same survey, Berger et al. (2005) find that compared with large banks, small banks are more likely to (i) communicate with their small-business customers through personal means such as face-to-face office visits, (ii) develop more long-term relationships with their customers, and (iii) lend to local businesses.

Petersen and Rajan (1994) examine the impact of customer relationships on the cost and availability of credit for small businesses. The study finds that firms pay higher interest rates when they have more than one lender, suggesting that a relationship with a single bank lowers a firm's borrowing costs. Further, the study finds that the length and extent of a firm's relationship with its bank lender have a significant effect on the supply of credit available to the firm. A firm will have a greater supply of credit from a bank the longer the firm's relationship with the bank, the more distinct services it receives from the bank, and the more concentrated its borrowing with the bank.

Community banks may have more information about the value of real estate in their communities than lenders with no local ties. Cortés (2012) presents evidence that residential mortgage lenders with a physical branch near the property being financed have better information about home-price fundamentals than nonlocal lenders. Home prices increased less from 2002 to 2006 in areas where lenders with local offices accounted for a higher percentage of residential mortgage loans. Moreover, home prices fell less from 2006 to 2009 in areas where more of the loans were made by local lenders. 


\section{Effects of Credit Scoring on the Advantages of Community Banks in Lending to Small Businesses}

Advances in information-processing technology have increased the amount of quantitative and other hard information about potential borrowers, suggesting the importance of developing close relationships with potential borrowers may have decreased over time. Survey evidence finds that community banks are increasingly using credit scoring and other quantitative information to evaluate small-business loans (Berger, Cowan, and Frame, 2011). Petersen and Rajan (2002) investigate how the physical distance between small businesses and their lenders relates to credit quality and loan performance. Historically, only the highest-quality small-business borrowers could obtain loans from distant banks, and Petersen and Rajan (2002) find that informationally opaque firms are located closer to their lenders. However, the study also finds that the distance between small businesses and their lenders has tended to increase over time and that lender-borrower interactions have become less personal. Further, the study finds that the relationship between borrower-lender distance and credit quality has diminished over time: This observation is consistent with the increased availability of hard information on the creditworthiness of potential small-business borrowers brought about by changes in information technology 6

Further research has found somewhat varied effects of increased use of credit-scoring technology on small-business lending. DeYoung, Glennon, and Nigro (2008) use a large dataset consisting of loans partially guaranteed by the Small Business Administration to investigate the relationships among the use of credit scoring, borrower-lender distance, and loan performance. The study finds that loan default rates increase with borrower-lender distance when credit scoring is not used, but that distance has no impact on default when credit scoring is used. However, DeYoung, Glennon, and Nigro (2008) find that banks that use credit scoring tend to experience higher loan default rates. The study speculates that banks that use credit-scoring models are willing to accept higher default rates because of ancillary benefits associated with higher loan volume, such as scale economies and higher fee income. Alternatively, credit-scoring underwriting processes may simply rely on less information about borrowers than underwriting based on customer relationships and thus lead to more loan approval errors. In any event, the results are similar to those of Berger et al. (2005), who find that banks that use credit-scoring methods to evaluate small-business loans experience higher nonperforming loan rates.

Increased use of credit scoring and other forms of information technology to obtain hard information about borrowers has likely somewhat diminished the comparative lending advantage of small, community-focused banks, particularly lending to small businesses. However, qualitative information obtained through personal contacts and customer relationships may remain important, especially for lending to borrowers lacking established credit histories, audited financial reports, and so forth.

\section{Performance of Community Banks in Urban and Rural Areas}

A few studies have examined differences in the types of markets where large and small banks locate offices and performance differences of loans to small businesses in different market 
types. These studies find a greater tendency of community banks to locate in smaller urban and rural markets than in large urban markets. Studies also find that loans made by small banks in rural markets tend to outperform those made by small banks in urban markets. Brickley, Linck, and Smith (2003) examine the location of banks and bank branches across urban and rural markets in California and Texas in 1998. Whereas California had allowed statewide branching since the 1920s, Texas prohibited branching before 1986. The different regulatory histories suggest that the ownership patterns observed in one state might differ from those of the other state. However, Brickley, Linck, and Smith (2003) find that in both California and Texas, the probability that a given bank office is owned by a bank with total assets exceeding $\$ 1$ billion increases with the population of the office's market. Further, controlling for population, the probability of large bank ownership is higher in large cities but smaller in suburban areas, smaller metropolitan areas, and rural markets.

DeYoung et al. (2012) compare the performance of small-business loans made by small banks in rural and urban markets. Using data on over 18,000 small-business loans made by community banks between 1984 and 2001, the study finds that loans made by rural banks have a significantly lower default rate than those made by small urban banks, with the lowest default rates found in the smallest rural markets. The authors attribute the performance advantage of community bank loans in rural markets to the "ruralness" of the borrower-lender relationshipthat is, where information, institutions, and culture are most conducive to relationship or "character" lending. The performance advantage diminishes for loans made by a bank in one rural market to a borrower in a different rural market, as well as with increasing distance between borrower and lender.

\section{Effects of Large Banking Organizations on the Performance of Rural Community Banks}

Studies of small bank performance in rural markets generally find that, rather than large banks posing a threat to rural community banks, community banks in rural counties may actually benefit from the presence of large multimarket banks. Pilloff (1999), for example, finds that the presence of one or more large multimarket banks boosts return on assets (ROA) of small banks that operate only within a single rural market.

Using a larger dataset covering the years 1996 through 2004, Hannan and Prager (2009) also find that the profitability of single-market banks in rural locations is directly affected by the presence of large, as well as small, multimarket banks. However, the direction of the impact on the ROA of a single-market bank located in a rural area appears to depend on the concentration of the market and the size of the single-market bank. The study finds that the presence of a large multimarket bank lowers the ROA of very small single-market rural banks, as well as those operating in highly concentrated markets. However, the presence of large (and small) multimarket banks boosts the ROA of a single-market bank of average asset size operating in a rural county with average market concentration. Finally, the study finds no strong relationship between the profit rates of small single-market banks located in urban areas and the presence of large multimarket banks. 
Like Pilloff (1999) and Hannan and Prager (2009), Cyree and Spurlin (2012) find that the presence of a large multimarket bank raises the ROA of small single-market banks in rural counties. However, when more than one large bank is present, the effect on small bank profit rates is reduced. Cyree and Spurlin (2012) also find that the presence of a single large bank lowers the profit efficiency of small banks in the market but the impact is lower when more than one large bank competes in the market. Taken together, the results for ROA and profit efficiency suggest that the presence of a single large multimarket bank generally reduces competition in a market, enabling all banks in the market to earn higher returns while operating less efficiently, whereas the presence of more than one large bank increases market competition and reduces profit rates for all banks in the market.

Pilloff (1999), Hannan and Prager (2009), and Cyree and Spurlin (2012) argue that their evidence indicates that the presence of large banking organization offices tends to reduce competition in rural banking markets. An alternative explanation, which Cyree and Spurlin (2012) attempt to control for in their study, is that large banking organizations tend to locate offices in rural banking markets where local banks can earn relatively high profits. Using either explanation, however, the evidence is consistent with the conclusion that large banking organizations do not drive out local community banks when they open offices in rural market areas.

\section{BANK DEPOSIT SHARES IN RURAL MARKETS}

The United States has 3,142 counties, 2,043 of which are rural (i.e., located outside metropolitan statistical areas [MSAs]). Among the rural counties, 2,017 had at least one office of a commercial bank or savings institution in $2012 .{ }^{-}$Banks of all sizes have offices in rural counties; but larger banks tend to have more of their offices and deposits in urban markets, whereas smaller banks have relatively more offices in rural counties. As of June 2012, 36 percent of the offices and 23 percent of the deposits of banking organizations with less than $\$ 1$ billion in assets were in rural counties. $\underline{-}$ By contrast, just 10 percent of the offices and 4 percent of the deposits of organizations with more than $\$ 50$ billion in assets were in rural counties.

The main focus of this article is on trends in the deposit shares of different-sized banking organizations in rural U.S. counties between 2001 and 2012. Community banks are often defined on the basis of their size, and studies commonly define community banks as banking organizations with total assets of either less than $\$ 1$ billion or less than $\$ 10$ billion. ${ }^{2}$ Here, we examine trends in the deposit shares of banking organizations in four size groups: (i) organizations with less than $\$ 1$ billion in assets (identified in the figures as "Small"), (ii) organizations with $\$ 1$ billion to 10 billion in assets ("Small-Mid"), (iii) organizations with $\$ 10$ billion to $\$ 50$ billion in assets ("Mid-Large"), and (iv) organizations with $\$ 50$ billion or more in total assets ("Large"). Our study includes all bank holding companies and independent commercial banks and savings institutions except credit card banks, bankers' banks, and other special purpose banks. We aggregate data for banks owned by holding companies to the holding company level and treat all offices of banks owned by a parent organization as belonging to that one organization. $\underline{10}$ Further, except as noted, we adjust data on the total assets of each organization for inflation using the consumer price index $(2006=100)$. 


\section{Gilbert and Wheelock}

Our study of market shares among banks with offices located in rural counties is limited to data on total deposits, which are available at the branch office level from the annual Summary of Deposits reports filed by banking organizations. ${ }^{11}$ Data on lending and other services provided by banks are not available by bank branches. Some large financial institutions are successful in marketing financial services to residents of rural areas without operating physical offices in rural areas. Given the lack of comprehensive data on such activities, however, we focus exclusively on the shares of deposits held by banks of different sizes in rural areas.

\section{National Market Share Trends}

Previous research on trends in rural deposit shares of different sizes and types of banks found that community banks lost market share during the 1980s and 1990s, whereas large banking organizations saw an increase in average market shares (Gilbert, 2000, and FDIC, 2012). Our study encompasses the period 2001-12 and thereby includes the financial crisis and recession of 2007-09, as well as the surrounding years. Thus, we examine how trends in the market shares of banks of different sizes may have been affected by the crisis and recession, as well as whether the trends identified in other studies continued after 2001. 12 We also investigate differences in market share trends in small rural counties (i.e., those with a population less than 10,000 according to the 2010 Census) compared with larger rural counties and counties located in urban areas. Further, we compare trends in different regions of the country. Previous research (Gilbert, 2000) found considerable regional differences in the presence and market shares of large banks in rural counties during the 1990s, which seemed to reflect the effects of state restrictions on branch banking and population density. Specifically, large banks had greater presence and market shares in (i) rural counties in states that permitted statewide branching in 1980 and (ii) more densely populated rural counties. Large banks were less often present or had smaller market shares in small rural counties in states that limited or prohibited branching in 1980. Many states relaxed their restrictions on branching during the 1980s, and the United States has permitted interstate branch banking since 1997. Hence, regional differences in the presence and market shares of large banks in rural areas might have been expected to dissipate over time if state branching restrictions were the principal reason for these differences before deregulation and within a few years thereafter.

Figure 1 reports average deposit shares for banking organizations of different sizes in U.S. rural counties. The shares, especially of both the smallest and the very largest organizations, were remarkably stable over the 12-year period despite high numbers of mergers, a major financial crisis and recession, and a large number of bank failures. In 2001, banks with less than $\$ 1$ billion in assets held on average 65 percent of rural county deposits, whereas in 2012, they held 64 percent. By contrast, very large banking organizations - those with assets in excess of $\$ 50$ billionheld on average 15 percent of rural county deposits in 2001 and 14 percent in 2012. Over the same years, the average share of rural deposits held by organizations with $\$ 1$ billion to $\$ 10$ billion in assets rose from 13 percent to 17 percent, whereas the average share of those banks with $\$ 10$ billion to $\$ 50$ billion in assets fell from 7 percent to 4 percent.

Next we consider differences between small rural counties-those with fewer than 10,000 inhabitants (in 2010) - and larger rural counties. Figures 2A and 2B present the average deposit 


\section{Figure 1}

\section{Average Deposit Shares in All Rural Counties}

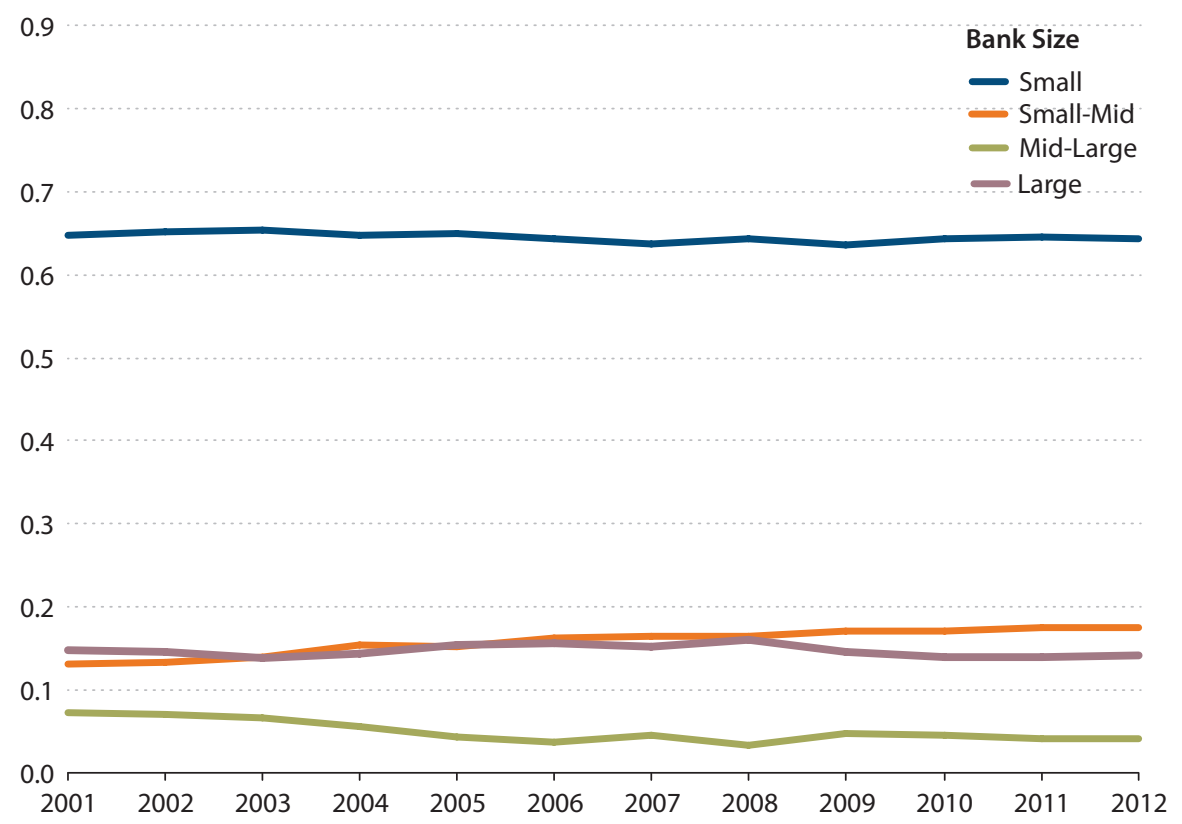

shares of each size of banking organization in small and large rural counties. Not surprisingly, the smallest organizations had larger average deposit shares in small rural counties than in larger rural counties, whereas the very largest banks had smaller shares in smaller rural counties than in larger rural counties. The trends over time in average deposit shares, however, were similar for small and larger rural counties. In both small and large rural counties, the smallest banks and the very largest banks both experienced slight declines in average deposit shares of 1 percentage point or less. By contrast, banks with assets of $\$ 1$ billion to $\$ 10$ billion saw increases in average share in both small and large rural counties, whereas banks with assets of $\$ 10$ billion to $\$ 50$ billion had small declines. Thus, across all rural U.S. counties, the average deposit shares of both the smallest and very largest banks changed little between 2001 and 2012, with little difference in trends between small and large rural counties.

\section{Regional Market Share Trends}

In 1980, rural market deposit shares of large banking organizations differed substantially across geographic regions, which Gilbert (2000) linked to regional differences in state branch banking laws. Large banks had larger market shares in rural counties of states that had long permitted statewide branching and smaller shares in states that limited branching. Small banking markets invariably had only small banks where branching was prohibited or restricted. However, in states that permitted statewide branching, such as California, many small communities and rural counties had branch offices of large banks. 


\section{Gilbert and Wheelock}

\section{Figure 2}

\section{Average Deposit Shares in Rural Counties}

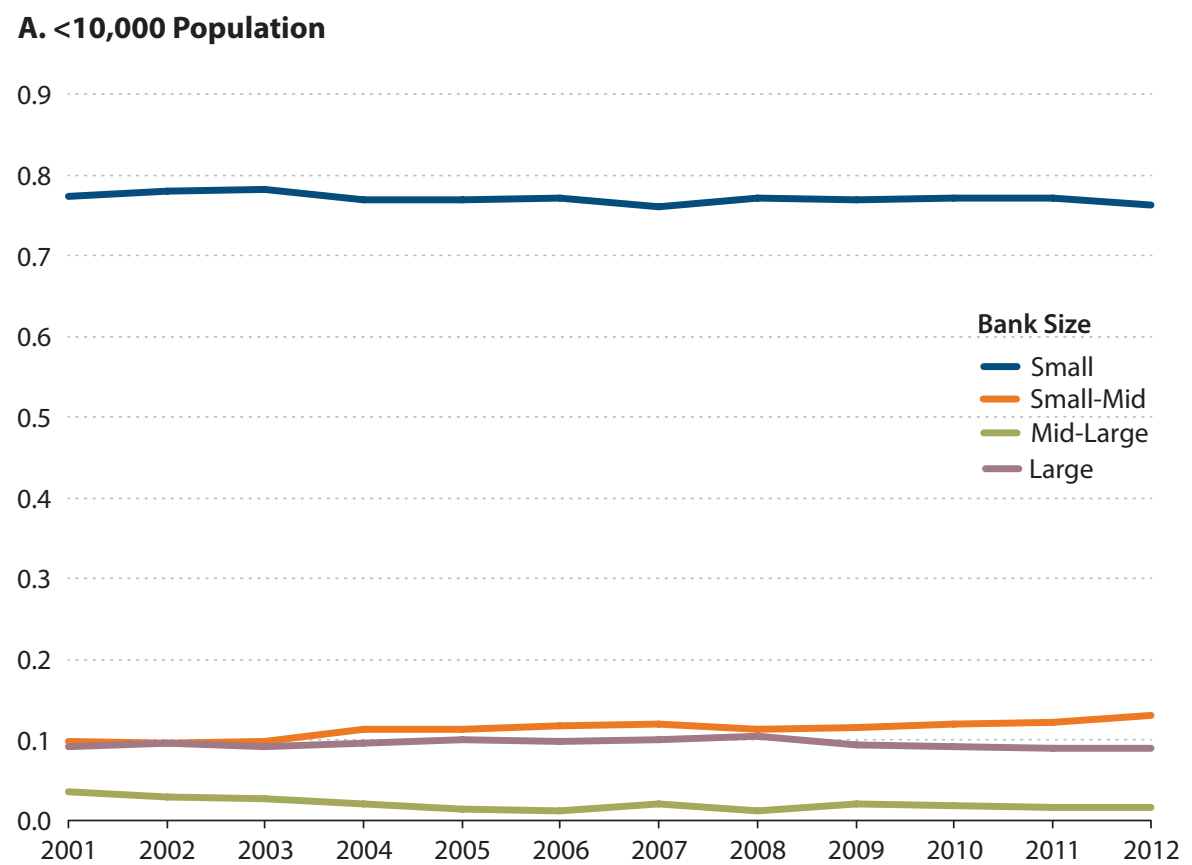

\section{B. $>10,000$ Population}

\begin{tabular}{ccc}
0.9 & Bank Size \\
& Small \\
& Small-Mid \\
& Mid-Large \\
0.7 & Large \\
\hline & & \\
\hline
\end{tabular}

0.5

0.4

0.3

0.2

0.1

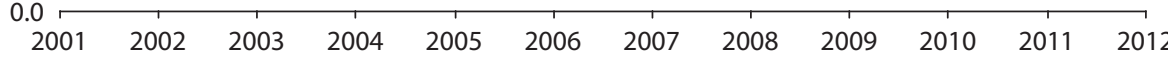




\section{Figure 3}

\section{Presence of Large Banks in U.S. Rural Counties}

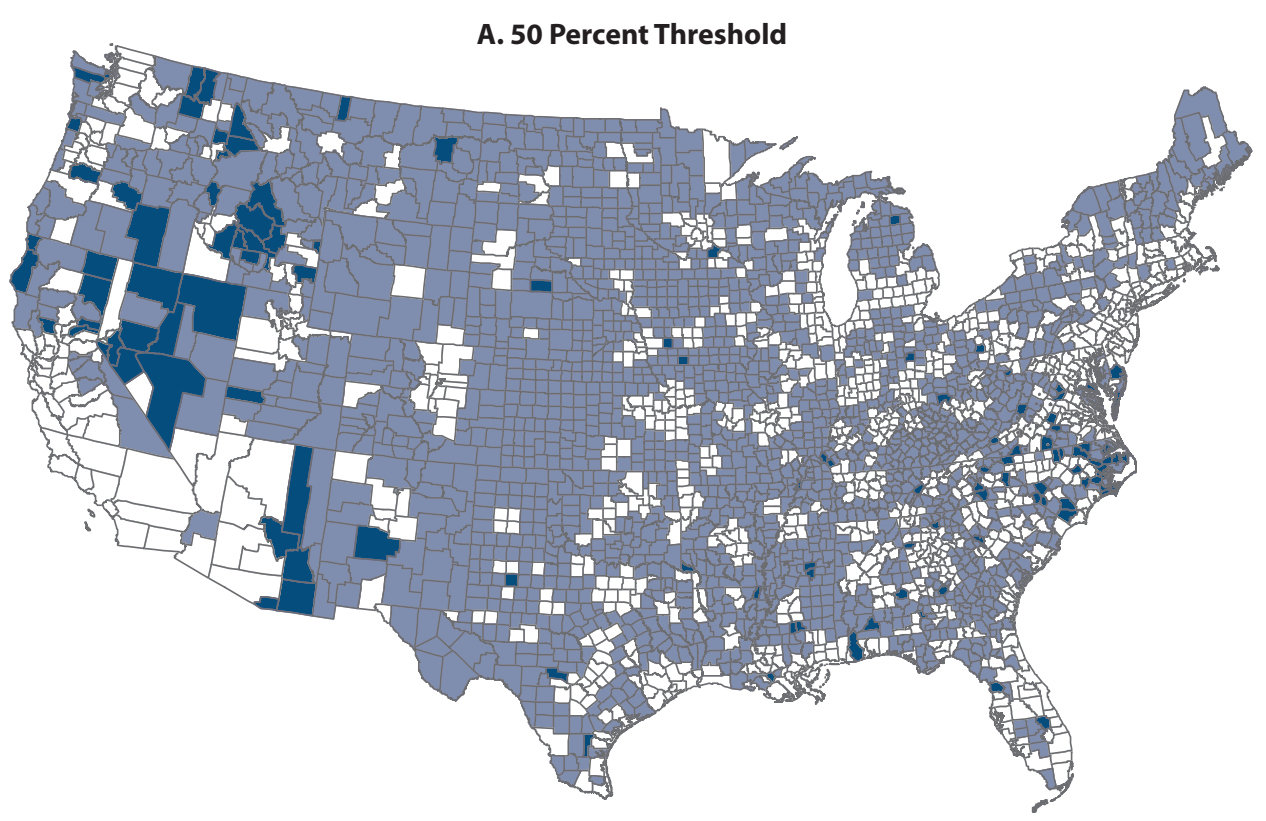

$\square$ Urban (MSA) counties or counties with no banks (2001-12)

Rural counties where large banks held less than 50 percent of total deposits

Rural counties where large banks held 50 percent or more of total deposits

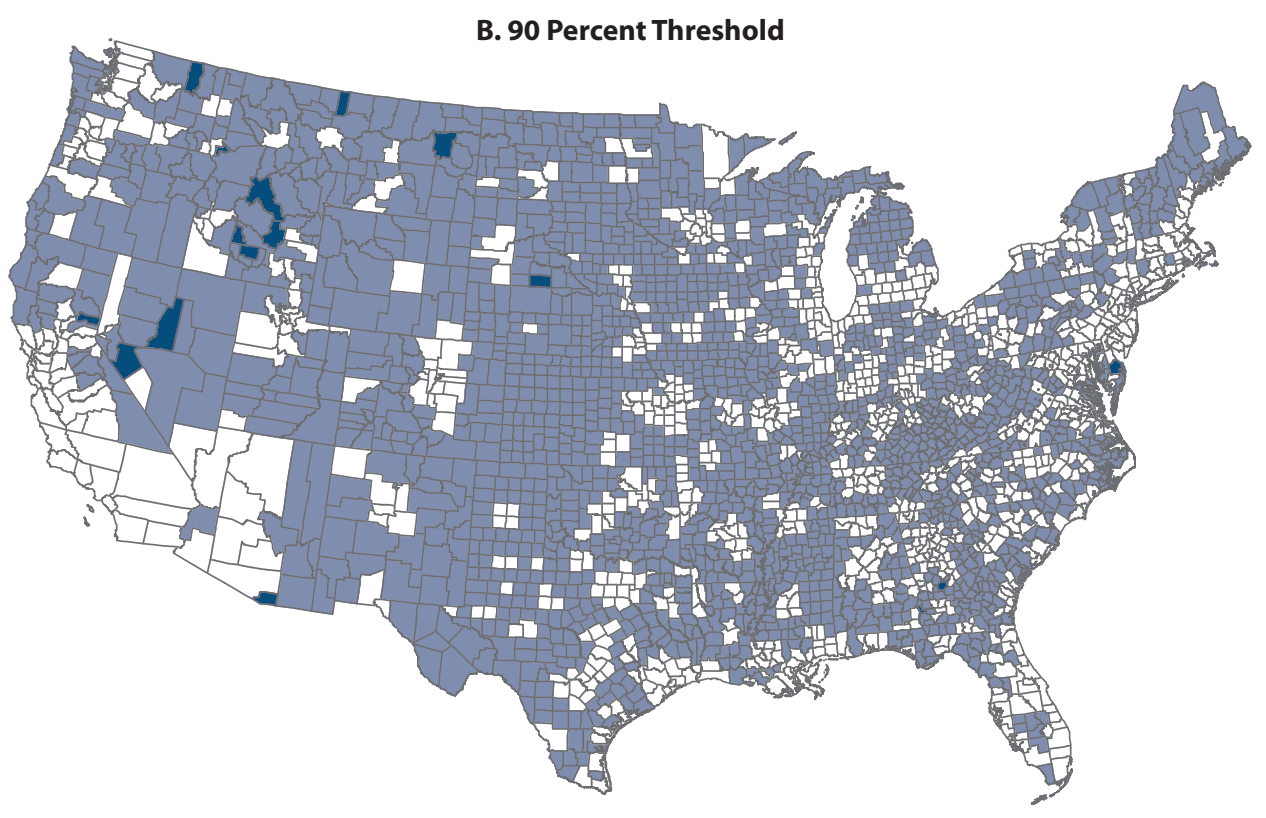

$\square$ Urban (MSA) counties or counties with no banks (2001-12)

Rural counties where large banks held less than 90 percent of total deposits

Rural counties where large banks held 90 percent or more of total deposits 


\section{Gilbert and Wheelock}

Many states relaxed or removed barriers to within-state branching between 1980 and 1995 . Many also began to permit entry by out-of-state bank holding companies. Interstate branching was permitted beginning in 1997. Gilbert (2000) found that the rural market shares of large banking organizations rose in most states during the 1980s and 1990s, but especially in those states that had limited or prohibited branching before 1980. He also found that large organizations generally had higher market shares in more densely populated counties and in low-populationdensity counties in states that permitted statewide branching in 1980.

Gilbert (2000) also found that some regional differences in market shares of large banks were still present in 1999. Specifically, large banks continued to have higher average rural deposit shares in regions where most states permitted statewide branching in 1980. Figures 3A and 3B show that these patterns were still present in 2012. Figure 3A shows that rural counties in which very large banking organizations held at least 50 percent of county deposits were more prevalent in the western states and on the East Coast, specifically in Maryland and North and South Carolina. The western states and these East Coast states allowed statewide branching in 1980. Similarly, Figure 3B shows that the few rural counties in which the very largest organizations held at least 90 percent of county deposits were primarily in western states that permitted statewide branching in 1980.

Figures $4 \mathrm{~A}$ through $4 \mathrm{I}$ show the average rural county deposit shares of different-sized banks in 2001, 2006, and 2012 by U.S. Census division. The states in each Census division are listed in Table 1, which also identifies states that permitted statewide branching in 1980. Similar to Gilbert's (2000) findings for the 1990s, Figures 4A through 4I show that the very largest banks had the largest rural deposit shares in regions where most states had long permitted branch banking, such as the South Atlantic, Mountain, and Pacific regions. The deposit shares of very large banks tend to be lower in regions where most states restricted branching in 1980, such as the West North Central, East South Central, and West South Central regions. An exception is New England, where most states permitted statewide branching in 1980 but rural deposit shares of the largest organizations were relatively low in the 2000s.

Turning to small banks, Figures 4A through $4 \mathrm{I}$ show that small banking organizations had the largest average rural deposit shares in regions where states tended to restrict branching before the 1980s. Small bank shares were especially high in the West North Central and West South Central regions, where nearly all states restricted branching before the 1980s. For example, in 2012, on average, 81 percent of the deposits of rural counties in the West North Central region were held by organizations with less than $\$ 1$ billion in assets. By contrast, on average, only 28 percent of the deposits of rural counties in the Pacific region were held by the smallest organizations. Data for 2001 through 2012 indicate little or no convergence across Census divisions in the rural deposit shares of community banks.

Figures $5 \mathrm{~A}$ and $5 \mathrm{~B}$ show more clearly the differences in the rural deposit shares of differentsized banks between branching and non-branching states in 1980. Although most states relaxed their restrictions on branch banking in the 1980s and interstate branching has been permitted since 1997, large differences remained as recently as 2012 in the average rural county deposit shares of banks grouped by size between states that permitted branching in 1980 and states that did not. 


\section{Figure 4}

\section{Average Deposit Shares in Rural Counties}
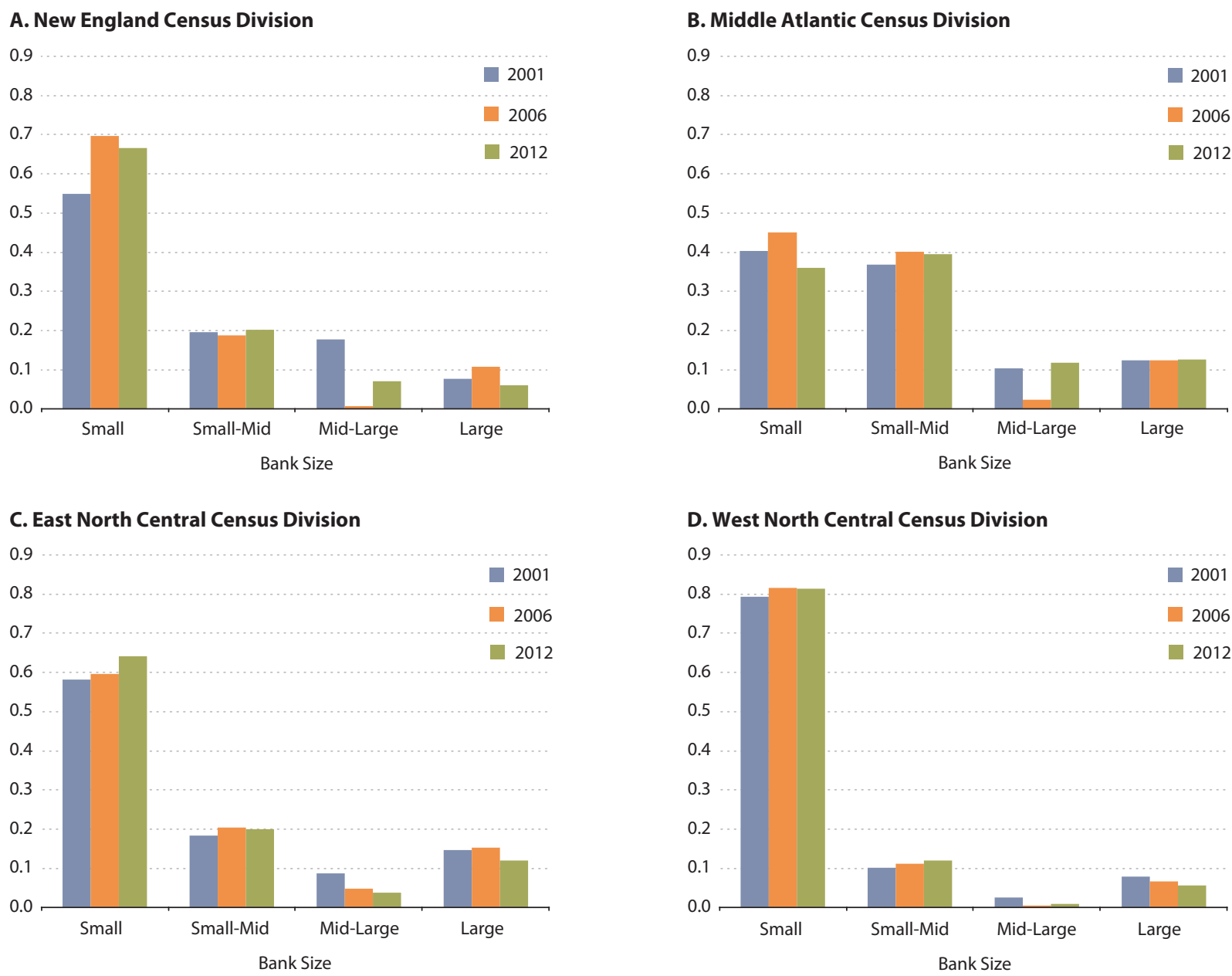

The persistence of regional differences in rural county deposit shares more than two decades after most states began to permit statewide branching and interstate banking is somewhat puzzling. However, subsequent to the enactment of the Riegel-Neal Interstate Banking and Branching Efficiency Act in 1994, many states imposed various limits on both interstate branching, including prohibitions on establishing branches de novo (rather than through acquisition of existing banks) and acquiring recently chartered banks. Several states also imposed statewide deposit caps. According to Rice and Strahan (2010), such restrictions continued to affect local banking market structures well after interstate branching was permitted in 1997. 


\section{Gilbert and Wheelock}

Figure 4, cont'd

\section{Average Deposit Shares in Rural Counties}

\section{E. South Atlantic Census Division}

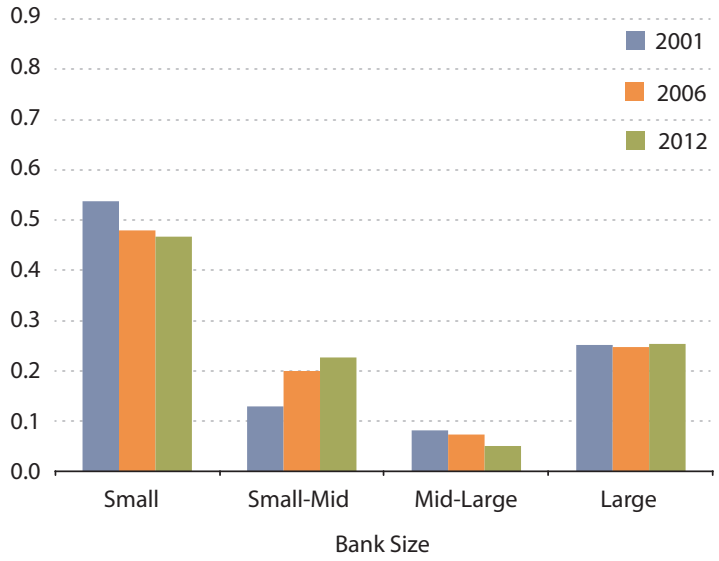

G. West South Central Census Division

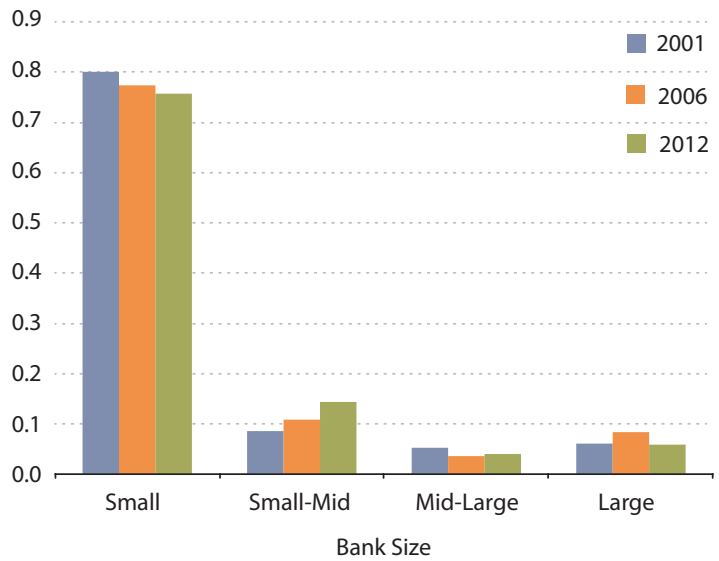

I. Pacific Census Division

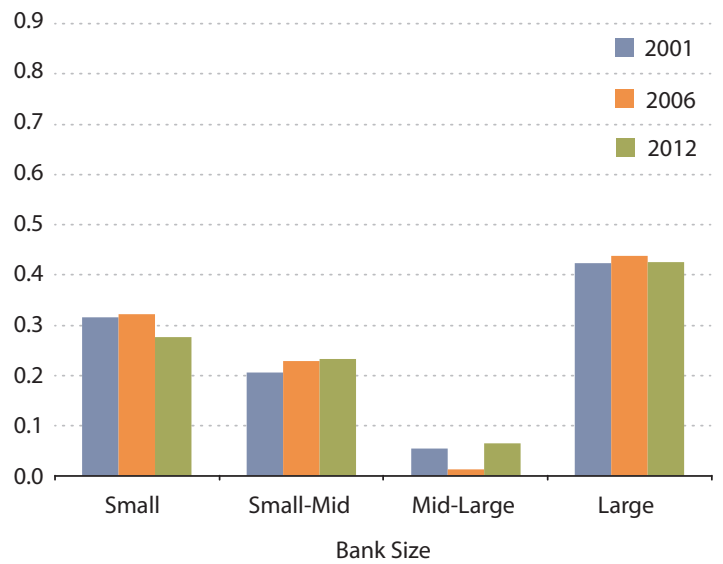

\section{F. East South Central Census Division}

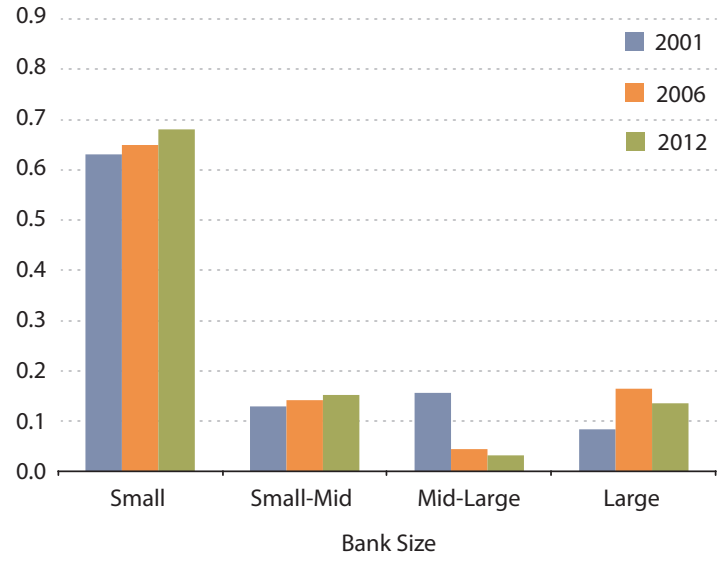

H. Mountain Census Division

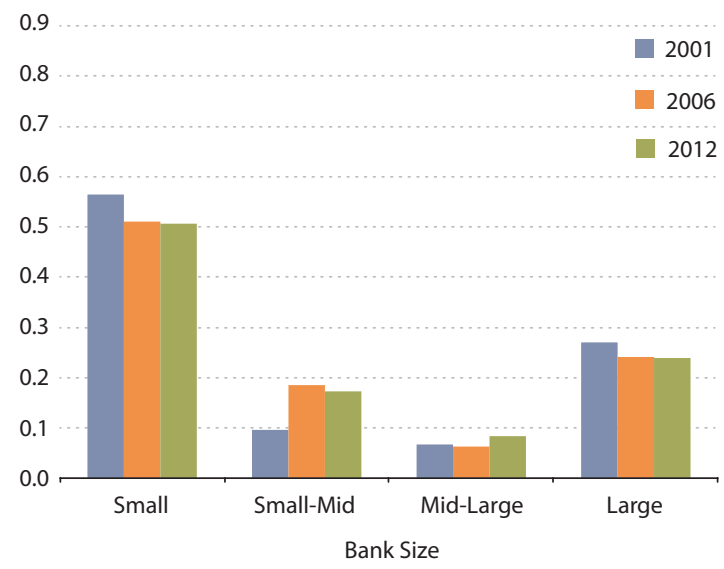


Table 1

States in Census Divisions

$\begin{array}{llll}\text { New England } & \text { West North Central } & \text { East South Central } & \text { Mountain } \\ \text { Connecticut* } & \text { lowa } & \text { Alabama } & \text { Arizona* } \\ \text { Maine* } & \text { Kansas } & \text { Kentucky } & \text { Colorado } \\ \text { Massachusetts } & \text { Minnesota } & \text { Mississippi } & \text { Idaho* } \\ \text { New Hampshire* } & \text { Missouri } & \text { Tennessee } & \text { New Mexico } \\ \text { Rhode Island* } & \text { Nebraska } & \text { West South Central } & \text { Montana } \\ \text { Vermont* } & \text { North Dakota } & \text { Arkansas } & \text { Utah } \\ \text { Middle Atlantic } & \text { South Dakota* } & \text { Louisiana } & \text { Nevada* } \\ \text { New Jersey* } & \text { South Atlantic } & \text { Oklahoma } & \text { Wyoming } \\ \text { New York* } & \text { Delaware* } & \text { Texas } & \text { Pacific } \\ \text { Pennsylvania } & \text { District of Columbia } & & \text { Alaska* } \\ \text { East North Central } & \text { Florida } & & \text { California* } \\ \text { Indiana } & \text { Georgia } & & \text { Hawaii* } \\ \text { Illinois } & \text { Maryland* } & & \text { Oregon* } \\ \text { Michigan } & \text { North Carolina* } & & \text { Washington* } \\ \text { Ohio } & \text { South Carolina* } & & \\ \text { Wisconsin } & \text { Virginia } & & \\ \text { West Virginia } & & \end{array}$

NOTE: States marked with an asterisk permitted statewide branching in 1980, subject to various restrictions on branching in the communities where banks had their headquarters (Gilbert, 2000).

\section{Large Bank Presence in Rural and Urban Markets}

After several years of increased branching, the number of bank branches in the United States has changed little since 2008, and several large banks have been pruning offices. Bank of America alone eliminated 193 branches in 2012, many of which were in rural markets and areas especially hit hard by falling home prices and the recent recession (Sidel, 2013). Community banks have acquired some branches shed by large banking organizations in rural and smaller urban markets that larger banks have abandoned (Peters, 2012). Still, large banking organizations continue to have a significant presence in many rural counties and, as shown in Figure 1, maintained a stable share of rural county deposits between 2001 and 2012.

Table 2, which provides information on the location of offices of banking organizations that held at least $\$ 50$ billion in assets in 2012, indicates that the presence of large banking organizations in rural counties varies substantially among large organizations. In general, organizations that only recently became bank holding companies or whose traditional business lines were insurance or other services besides commercial banking (e.g., Goldman Sachs Group, MetLife, and American Express Company) have banking offices in fewer counties than holding companies whose traditional business was dominated by commercial banking. Similarly, Bank of New 


\section{Figure 5}

\section{Average Deposit Shares in Rural Counties}
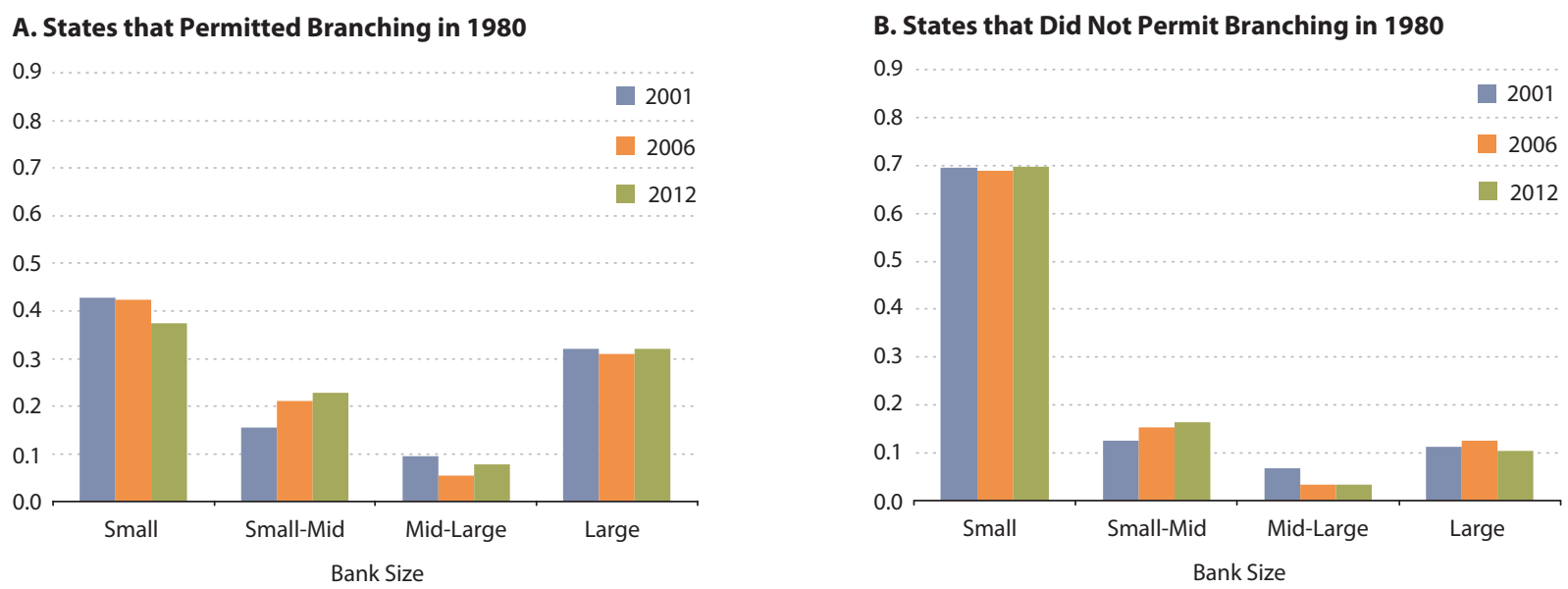

York Mellon Corporation and State Street Corporation, which focus mainly on providing financial services to other financial institutions rather than retail customers, have no offices in rural counties. Other large organizations (e.g., Ally Financial and Discover Financial) offer specific financial services to consumers throughout the country from offices in one or two urban locations using advertising and communications technology.

By contrast, the large banking organizations that operate many branch offices all had their roots in commercial banking. Wells Fargo \& Company and Bank of America Corporation, for example, have offices in the largest number of counties throughout the United States. The percentage of corporate banking offices and deposit shares in rural counties varies somewhat across even the traditional commercial banking organizations, however; this largely reflects the different regions of the country where the organizations are currently or were originally headquartered or where the organizations have made significant acquisitions. For example, Wells Fargo \& Company, U.S. Bancorp, Regions Financial Corporation, and BB\&T Corporation all have branches in numerous rural counties. Wells Fargo and BB\&T also have comparatively high average deposit shares in rural counties in which they have locations. The headquarters of both Wells Fargo and BB\&T are in states that have long permitted statewide branch bankingCalifornia in the case of Wells Fargo and North Carolina in the case of BB\&T. Wells Fargo also has numerous branches in North Carolina as a result of its acquisition of Wachovia Corporation in 2008. Thus, the relatively high average rural deposit shares of these organizations is consistent with evidence that large organizations generally have larger rural deposit shares in states that permitted branching in 1980 . 


\section{Table 2}

Large Banking Organizations in Urban and Rural Counties: Number of Counties and Average Deposit Share in Counties Where They Have Offices (June 2012)

\begin{tabular}{|c|c|c|c|c|c|c|c|c|c|}
\hline \multirow[b]{2}{*}{ Banking organization } & \multirow[b]{2}{*}{$\begin{array}{l}\text { Total assets } \\
\text { (\$ millions) }\end{array}$} & \multicolumn{4}{|c|}{ Number of counties by type } & \multicolumn{4}{|c|}{ Average deposit share by county type } \\
\hline & & $\begin{array}{c}\text { Urban } \\
\text { (total } 1,097)\end{array}$ & $\begin{array}{c}\text { Rural } \\
\text { (total } 2,017 \text { ) }\end{array}$ & $\begin{array}{c}\text { Small- } \\
\text { population } \\
\text { rural } \\
\text { (total } 625 \text { ) }\end{array}$ & $\begin{array}{c}\text { Larger- } \\
\text { population } \\
\text { rural } \\
\text { (total 1,392) }\end{array}$ & Urban & Rural & $\begin{array}{c}\text { Small- } \\
\text { population } \\
\text { rural }\end{array}$ & $\begin{array}{c}\text { Larger- } \\
\text { population } \\
\text { rural }\end{array}$ \\
\hline JPMorgan Chase \& Co. & $2,290,146$ & 344 & 98 & 1 & 97 & 0.10 & 0.12 & 0.08 & 0.12 \\
\hline Bank of America Corporation & $2,162,083$ & 477 & 236 & 10 & 226 & 0.11 & 0.12 & 0.41 & 0.10 \\
\hline Citigroup Inc. & $1,916,451$ & 117 & 14 & 3 & 11 & 0.04 & 0.06 & 0.09 & 0.05 \\
\hline Wells Fargo \& Company & $1,336,204$ & 526 & 404 & 67 & 337 & 0.17 & 0.21 & 0.42 & 0.17 \\
\hline Goldman Sachs Group, Inc. & 948,981 & 4 & 0 & 0 & 0 & 0.06 & & & \\
\hline MetLife, Inc. & 825,188 & 1 & 0 & 0 & 0 & 0.24 & & & \\
\hline U.S. Bancorp & 353,136 & 283 & 313 & 39 & 274 & 0.09 & 0.12 & 0.26 & 0.10 \\
\hline Bank of New York Mellon Corporation & 330,490 & 42 & 0 & 0 & 0 & 0.01 & & & \\
\hline PNC Financial Services Group, Inc. & 299,712 & 297 & 138 & 1 & 137 & 0.09 & 0.14 & 0.64 & 0.14 \\
\hline Capital One Financial Corporation & 296,698 & 90 & 34 & 1 & 33 & 0.11 & 0.14 & 0.33 & 0.13 \\
\hline State Street Corporation & 200,369 & 1 & 0 & 0 & 0 & 0.38 & & & \\
\hline Ally Financial Inc. & 178,560 & 1 & 0 & 0 & 0 & 0.20 & & & \\
\hline BB\&T Corporation & 178,529 & 260 & 172 & 13 & 159 & 0.15 & 0.20 & 0.43 & 0.19 \\
\hline SunTrust Banks, Inc. & 178,307 & 192 & 62 & 2 & 60 & 0.12 & 0.12 & 0.37 & 0.11 \\
\hline American Express Company & 146,890 & 1 & 0 & 0 & 0 & 0.10 & & & \\
\hline Regions Financial Corporation & 122,345 & 226 & 201 & 12 & 189 & 0.10 & 0.16 & 0.39 & 0.15 \\
\hline Fifth Third Bancorp & 117,543 & 155 & 73 & 2 & 71 & 0.09 & 0.12 & 0.23 & 0.12 \\
\hline Northern Trust Corporation & 94,456 & 41 & 0 & 0 & 0 & 0.02 & & & \\
\hline Keycorp & 86,741 & 128 & 75 & 1 & 74 & 0.07 & 0.11 & 1.00 & 0.10 \\
\hline M\&T Bank Corporation & 80,808 & 100 & 34 & 1 & 33 & 0.08 & 0.08 & 0.20 & 0.08 \\
\hline Discover Financial Services & 73,256 & 1 & 1 & 0 & 1 & 0.00 & 0.93 & & 0.93 \\
\hline Charles Schwab Bank & 72,156 & 5 & 0 & 0 & 0 & 0.19 & & & \\
\hline Comerica Incorporated & 62,757 & 49 & 4 & 0 & 4 & 0.05 & 0.11 & & 0.11 \\
\hline
\end{tabular}




\section{Gilbert and Wheelock}

\section{CONCLUSION}

If the community bank business model is apt to succeed anywhere, it should be in rural markets. The cost of relationship lending - a hallmark of community banking-may be lower in rural areas than in urban areas, and rural markets likely have higher percentages of borrowers for whom there is limited quantitative information. Data on the shares of rural county bank deposits held by banking organizations of different sizes indicate that, on the whole, large banks have not driven small banks from rural banking markets. Although the deposit shares of small banks in rural counties and small towns declined during the 1980s and 1990s, between 2001 and 2012, the share of rural county deposits held by banks with less than $\$ 1$ billion in assets changed little, as did the share held by banks with more than $\$ 50$ billion in assets. Recent sales of rural-market branches by large banking organizations to smaller banks suggest that large banks may find rural markets less profitable than do small banks.

Perhaps the impact of advances in information-processing technology in altering the competitive balance between large and small banks occurred prior to 2001, but other explanations for the recent stability of deposit shares of different-sized banks in rural markets are possible. Rural counties have generally experienced slower population and economic growth than urban areas in recent years, and large banks may have chosen to focus their operations in urban markets and cede business to smaller banks in slower-growing and less-profitable rural markets. If that explanation is true, then the impact of technological change may produce further shifts in the competitive balance between large and small banks as large banks eventually devote resources to building market share in the more profitable rural areas. Data on the rural banking offices of individual large banking organizations may indicate another explanation for the observations on deposit shares in rural markets: Perhaps changes in technology have made it easier over time for large organizations to provide financial services without networks of physical offices. Of course, the structure of banking markets can also be affected by regulation, antitrust enforcement, and changes in the macroeconomic environment. It is beyond the scope of this article to test alternative explanations for changes in the average market shares of banks of different sizes. However, the evidence that the average rural county deposit share of large banking organizations did not increase between 2001 and 2012 is at least suggestive that small banks remain competitive in their main market segments.

The future, of course, is less certain. Advances in information technology continue to lower the cost of acquiring hard information about potential borrowers and facilitate obtaining banking and other financial services by means of the Internet. Access to a brick-and-mortar bank office has become less important for many bank customers, which may favor larger banks that can spread the fixed costs of information technology over more customers. $\underline{13}$ However, evidence from micro studies of community banks (such as Gilbert, Meyer, and Fuchs, 2013) indicates that well-managed community banks can thrive even in challenging times. The relative stability of deposit shares of small banks over the past decade suggests further that community banks, as a group, remain competitive with larger banking organizations, at least in markets where informationally opaque borrowers are most prevalent. 


\section{NOTES}

1 Data on the number of commercial banks and offices are from the Federal Deposit Insurance Corporation (FDIC), Table CB03 (http://www2.fdic.gov/hsob/HSOBRpt.asp).

2 Data on the total assets and deposits held by commercial banks of various sizes are available from the FDIC's Statistics on Banking (http://www2.fdic.gov/SDI/SOB/).

3 See Stern and Feldman (2009) or Rosenblum (2011) for discussions about too-big-to-fail policy.

4 Some evidence in support of this assumption is discussed in DeYoung et al. (2012).

$\underline{5}$ See Berger et al. (2005).

6 DeYoung et al. (2011) find that the increased use of credit scoring has been an important cause of the increase in average distance between small businesses and their lenders, especially since 1993.

7 Credit unions and other types of financial intermediaries are also present in many rural markets. However, our data include only commercial banks and savings institutions, which are the only depository institutions for which comprehensive data on the location of branch offices are available.

8 Banking organizations include bank and thrift holding companies and commercial banks and savings institutions that are not owned by a holding company.

9 A few studies use more-refined definitions of community banks. For example, the FDIC (2012) includes all banking organizations with less than $\$ 1$ billion of assets (indexed for inflation to 2010), as well as some larger organizations with high ratios of loans to assets or core deposits to assets, or those that operate in few markets. However, in the absence of a standard, widely accepted definition of community banks, we group banks solely on the basis of asset size.

10 Some bank holding companies are controlled by other holding companies. In those cases, we aggregate all data to the level of the top holding company.

11 These data are available from the FDIC (http://www2.fdic.gov/sod/).

12 The FDIC (2012) found that the average rural market share of community banks remained stable during 2001-11. As noted previously (endnote 9), the FDIC (2012) defines community banks on the basis of both size and scope criteria. Hence, our study provides evidence on whether market share trends are sensitive to the use of the alternative criteria for defining community banks.

13 See Wheelock and Wilson (2012) for more discussion and evidence of increasing returns to scale in banking.

\section{REFERENCES}

Berger, Allen N. "The Economic Effects of Technological Progress: Evidence from the Banking Industry." Journal of Money, Credit, and Banking, April 2003, 35(2), pp. 141-76.

Berger, Allen N.; Cowan, Adrian M. and Frame, W. Scott. "The Surprising Use of Credit Scoring in Small Business Lending by Community Banks and the Attendant Effects on Credit Availability, Risk, and Profitability." Journal of Financial Services Research, April 2011, 39(1-2), pp. 1-17.

Berger, Allen N.; Miller, Nathan H.; Petersen, Mitchell A.; Rajan, Raghuram G. and Stein, Jeremy C. “Does Function Follow Organizational Form? Evidence from the Lending Practices of Large and Small Banks." Journal of Financial Economics, May 2005, 76(2), pp. 237-69.

Bernanke, Ben S. "Community Banking and Community Bank Supervision." Remarks at the Independent Community Bankers of America National Convention and Techworld, Las Vegas, Nevada, March 8, 2006; http://www.federalreserve.gov/newsevents/speech/bernanke20060308a.htm.

Brickley, James A.; Linck, James S. and Smith, Clifford W. Jr. "Boundaries of the Firm: Evidence from the Banking Industry." Journal of Financial Economics, December 2003, 70(3), pp. 351-83.

Cole, Rebel A.; Goldberg, Lawrence G. and White, Lawrence J. “Cookie Cutter vs. Character: The Micro Structure of Small Business Lending by Large and Small Banks." Journal of Financial and Quantitative Analysis, June 2004, 39(2), pp. 227-51. 


\section{Gilbert and Wheelock}

Cortés, Kristle Romero. “Did Local Lenders Forecast the Bust? Evidence from the Real Estate Market." Working Paper No. 12-26, Federal Reserve Bank of Cleveland, November 2012; http://www.clevelandfed.org/research/workpaper/2012/wp1226.pdf.

Cyree, Ken B. and Spurlin, W. Paul. "The Effects of Big-Bank Presence on the Profit Efficiency of Small Banks in Rural Markets." Journal of Banking and Finance, September 2012, 36(9), pp. 2593-603.

DeYoung, Robert; Frame, W. Scott; Glennon, Dennis and Nigro, Peter. "The Information Revolution and Small Business Lending." Journal of Financial Services Research, April 2011, 39(1), pp. 19-33.

DeYoung, Robert; Glennon, Dennis and Nigro, Peter. "Borrower-Lender Distance, Credit Scoring, and Loan Performance: Evidence from Informationally-Opaque Small Business Borrowers." Journal of Financial Intermediation, January 2008, 17(1), pp. 113-43.

DeYoung, Robert; Glennon, Dennis; Nigro, Peter and Spong, Kenneth. "Small Business Lending and Social Capital: Are Rural Relationships Different?" CBE Working Paper No. 2012-1, KU Center for Banking Excellence, University of Kansas School of Business, June 2012; http://www.business.ku.edu/sites/businessdev.drupal.ku.edu/files/docs/ CBE\%20WP\%202012-1\%20DeYoung\%20Glennon\%20Nigro\%20Spong.pdf.

DeYoung, Robert; Hunter, William C. and Udell, Gregory F. “The Past, Present, and Probable Future for Community Banks." Journal of Financial Services Research, April 2004, 25(2-3), pp. 85-133.

Federal Deposit Insurance Corporation. FDIC Community Banking Study. Washington, DC: Federal Deposit Insurance Corporation, December 2012; http://www.fdic.gov/regulations/resources/cbi/study.html.

Gilbert, R. Alton. “Nationwide Branch Banking and the Presence of Large Banks in Rural Areas.” Federal Reserve Bank of St. Louis Review, May/June 2000, 82(3), pp. 13-28; http://research.stlouisfed.org/publications/review/00/05/05ag.pdf.

Gilbert, R. Alton; Meyer, Andrew P. and Fuchs, James W. "The Future of Community Banks: Lessons from Banks That Thrived During the Recent Financial Crisis." Federal Reserve Bank of St. Louis Review, March/April 2013, 95(2), pp. 115-43; http://research.stlouisfed.org/publications/review/13/03/gilbert.pdf.

Hannan, Timothy H. and Prager, Robin A. "The Profitability of Small Single-Market Banks in an Era of Multi-Market Banking." Journal of Banking and Finance, February 2009, 33(2), pp. 263-71.

Peters, Andy. "Community Banks Swoop in on B of A's Unwanted Branches." American Banker, December 28, 2012; http://www.americanbanker.com/issues/177 249/community-banks-swoop-in-on-b-of-a-s-unwanted-branches1055494-1.html.

Petersen, Mitchell A. and Rajan, Raghuram G. "The Benefits of Lending Relationships: Evidence from Small Business Data." Journal of Finance, March 1994, 49(1), pp. 3-37.

Petersen, Mitchell A. and Rajan, Raghuram G. “Does Distance Still Matter? The Information Revolution in Small Business Lending." Journal of Finance, December 2002, 57(6), pp. 2533-70.

Pilloff, Steven J. "Does the Presence of Big Banks Influence Competition in Local Markets?" Journal of Financial Services Research, May 1999, 15(3), pp. 159-77.

Rice, Tara and Strahan, Philip E. "Does Credit Competition Affect Small-Firm Finance?" Journal of Finance, June 2010, 65(3), pp. 861-89.

Rosenblum, Harvey. "Choosing the Road to Prosperity: Why We Must End Too Big to Fail—Now." Federal Reserve Bank of Dallas Annual Report 2011, pp. 2-23; http://www.dallasfed.org/assets/documents/fed/annual/2011/ar11 b.pdf.

Sidel, Robin. "After Years of Growth, Banks Are Pruning Their Branches." Wall Street Journal, March 31, 2013; http://online.wsj.com/article/SB10001424127887323699704578326894146325274.html.

Stein, Jeremy C. "Information Production and Capital Allocation: Decentralized versus Hierarchical Firms." Journal of Finance, October 2002, 57(5), pp. 1891-921.

Stern, Gary H. and Feldman, Ron J. Too Big to Fail: The Hazards of Bank Bailouts. Washington, DC: Brookings Institution Press, 2009.

Wheelock, David C. and Paul W. Wilson. “Do Large Banks Have Lower Costs? New Estimates of Returns to Scale for U.S. Banks." Journal of Money, Credit, and Banking, February 2012, 44(1), pp. 171-99. 